\title{
ILCOR's revised Covid-19 defibrillation recommendation requires a new approach to training
}

\author{
John A. Stewart
}

\begin{abstract}
In-hospital resuscitation practices have changed by necessity in the Covid-19 era, principally due to precautions intended to protect caregivers from infection. This has resulted in serious delays in resuscitation response. ILCOR has recently modified its guidelines to separate defibrillation from other interventions, recognizing that shock success is extremely time-dependent and that defibrillation poses relatively little risk of Covid-19 transmission. The new recommendation calls for sending one caregiver into the isolation room in order to initiate bedside monitoring and defibrillate if indicated, while the code team is donning their personal protective equipment. Implementing this change requires focused training in that specific role. This can be accomplished by intensively training a subset of clinical staff to assume the responsibility and act without hesitation when a code occurs. Focused defibrillation training promises to avoid compromising the care of patients experiencing tachyarrhythmic arrests in the setting of Covid-19. Such a training program might even result in better survival than before the pandemic for this subset of patients.
\end{abstract}

Keywords: In-hospital cardiac arrest, In-hospital resuscitation, Covid-19, Defibrillation, Training

\section{Background}

The Covid-19 pandemic has stimulated changes to many aspects of healthcare, including the response to cardiac arrests both outside of and within hospitals. Potential transmission of Covid-19 to caregivers is a central concern, and personal protective equipment (PPE) is used to protect caregivers from infection. In hospitals, the basic protections are droplet and contact isolation of suspected Covid-19 patients, with airborne precautions recommended for aerosol-generating procedures (AGPs) [1]. These precautions necessarily cause treatment delays.

With their recent revision, the International Liaison Committee on Cardiopulmonary Resuscitation's (ILCOR's) guidelines reflect these PPE guidelines but also specifically identify defibrillation as unlikely to generate aerosols,

Correspondence: jastewart325@gmail.com 9407 Linden Ave. N, Seattle, WA 98103, USA consequently recommending that hospitals "consider attempting defibrillation [for patients with tachyarrhythmic arrests] before donning personal protective equipment (PPE) for aerosol generating procedures" and before starting chest compressions [2] -echoing an approach developed in 2003 in response to the severe acute respiratory syndrome coronavirus (SARS-CoV) crisis [3]. This is a change from the former goal (rarely achieved in practice) of starting chest compressions and monitoring/defibrillation simultaneously.

Even before the Covid-19 pandemic, there were good reasons to focus attention and resources on rapid defibrillation. Defibrillation is often thought of as just one of many elements of emergency cardiac care, but it is in fact the only definitive treatment for any type of cardiac arrest--and success decreases very rapidly with time. Some 20 years ago, American Heart Association and ILCOR resuscitation leaders acknowledged the problem of

(c) The Author(s). 2020 Open Access This article is licensed under a Creative Commons Attribution 4.0 International License, which permits use, sharing, adaptation, distribution and reproduction in any medium or format, as long as you give appropriate credit to the original author(s) and the source, provide a link to the Creative Commons licence, and indicate if changes were made. The images or other third party material in this article are included in the article's Creative Commons licence, unless indicated otherwise in a credit line to the material. If material is not included in the article's Creative Commons licence and your intended use is not permitted by statutory regulation or exceeds the permitted use, you will need to obtain permission directly from the copyright holder. To view a copy of this licence, visit http://creativecommons.org/licenses/by/4.0/ The Creative Commons Public Domain Dedication waiver (http://creativecommons.org/publicdomain/zero/1.0/) applies to the data made available in this article, unless otherwise stated in a credit line to the data. 
delayed defibrillation and began promoting automated external defibrillation in hospitals [4], resulting in the widespread adoption of dual-mode (automated and manual) defibrillators by hospitals. That approach failed to improve survival (no change for tachyarrhythmic arrests, lower survival for other arrhythmias) [5], and interest in the problem waned afterward.

\section{Main text}

The rationale for ILCOR's revised defibrillation recommendation is simply that defibrillation success is clearly very time-dependent [6] and donning PPE necessarily causes delays in treatment. Since defibrillation is not thought to produce significant aerosols (i.e., is not an AGP), it should not be delayed to put on full PPE. Instead, one person should immediately take the monitor/defibrillator into the room, initiate bedside cardiac monitoring, and defibrillate if indicated, while others are donning their PPE. An additional consideration is that defibrillation can be done from more than $2 \mathrm{~m}$ distant from the patient, further decreasing transmission risk [7].

This approach can complicate resuscitation efforts. If several caregivers are immediately at the scene, as is commonly the case, the caregiver designated to go first into the isolation room should be both willing to perform the role and proficient in defibrillation. Assigning that role on the spot will almost certainly involve a significant delay. One alternative would be to assign resuscitation team roles in advance, but there would be no way to ensure that the person designated to defibrillate could be on the scene quickly. In addition, the act of defibrillation can be intimidating for a number of reasons (the sudden call to perform in a life-or-death situation; fear--albeit largely groundless--of injury to oneself, the patient, or others), and concerning delays have been documented repeatedly in clinical simulations $[8,9]$. Add to these factors the challenge of entering the room and being expected to perform alone, without full PPE, and the task can appear quite daunting.

Exploration of another approach is warranted-especially now, with the current Covid-19 pandemic. A cadre of nurses or other caregivers (perhaps one in four) could be trained intensively for one specific role in every code: to provide initial monitoring and defibrillation as quickly as possible [10]. For Covid-19 arrests, they would automatically be designated as the first to enter the room, perhaps identified by distinctive ID badges, while other caregivers donned their PPE. They could defibrillate if indicated-saving precious minutes-and withdraw as others arrived, whether to don their own PPE and rejoin the team or to resume other duties. If defibrillation was successful, the code would likely be shortened, thus decreasing the risk of Covid-19 transmission to caregivers while also giving the patient a decent chance to survive.
Most resuscitation interventions assume a supine patient, but Covid-19 patients are frequently positioned prone. In the event of a code they must be turned over for most emergency interventions, requiring multiple staff and additional delay [11]. However, defibrillation can easily be done before this major effort, with electrode pads applied in bi-axillary or postero-lateral (left mid-axillary line and right scapula) position [12].

Focused defibrillation training promises to decrease confusion and delay in Covid-19 resuscitation efforts. It may also help with some of the hard decisions caregivers face about limiting or withholding resuscitation efforts [13]. Defibrillating first could provide a reasonable endpoint for efforts in some cases, given that survival from other presenting arrhythmias is very low [14].

\section{Conclusion}

Resuscitation guidelines are by necessity changing in the setting of Covid-19, but delivery of defibrillation need not be compromised and might even be improved by focused defibrillation training. Caregivers would not be exposed to significant additional risk, and patients with tachyarrhythmic arrests would be given their first and best chance of survival.

\section{Abbreviations}

PPE: Personal protective equipment; AGP: Aerosol generating procedure; ILCOR: International liaison committee on cardiopulmonary resuscitation

\section{Acknowledgements \\ None}

Author's contributions

JAS is the sole author. The author read and approved the final manuscript.

Funding

None.

Availability of data and materials

Not applicable.

Ethics approval and consent to participate

Not applicable.

Consent for publication

Granted.

Competing interests

The authors declare that they have no competing.

Received: 23 July 2020 Accepted: 28 October 2020

Published online: 07 November 2020

References

1. World Health Organization. Rational use of personal protective equipment for coronavirus disease (COVID-19) and considerations during severe shortages-Interim guidance. 6 April 2020. WHO/2019-nCov/IPC_PPE_use/ 2020.3. Accessed July 23.

2. Perkins GD, Morley PT, Nolan JP, et al. International liaison committee on resuscitation: COVID-19 consensus on science, treatment recommendations and task force insights. Resuscitation. 2020; 151:145-147. doi:https://doi.org/ 10.1016/j.resuscitation.2020.04.035. Accessed July 2.

3. Mclsaac S, Wax R, Long B, Hicks C, Vaillancourt C, Ohle R, Atkinson P. Just the Facts: Protected code blue-Cardiopulmonary resuscitation in the emergency 
department during the coronavirus disease 2019 pandemic. CJEM. 2020;22(4): 431-4. https://doi.org/10.1017/cem.2020.379 Accessed July 2.

4. The American Heart Association in Collaboration with the International Liaison Committee on Resuscitation. Guidelines 2000 for Cardiopulmonary Resuscitation and Emergency Cardiovascular Care, Part 4: the automated external defibrillator: key link in the chain of survival. Circulation. 2000;102(8 Suppl) I-60-76.

5. Chan PS, Krumholz HM, Spertus JA, et al. American heart association national registry of cardiopulmonary resuscitation (NRCPR) investigators. Automated external defibrillators and survival after in-hospital cardiac arrest. JAMA. 2010;304(19):2129-36. https://doi.org/10.1001/jama.2010.1576 Accessed July 2. 6.

6. Chan PS, Krumholz HM, Nichol G, Nallamothu BK. American heart association national registry of cardiopulmonary resuscitation investigators. Delayed time to defibrillation after in-hospital cardiac arrest. N Engl J Med. 2008:358(1):9-17. https://doi.org/10.1056/NEJMoa0706467 Accessed July 2.

7. Simonds AK. 'Led by the science', evidence gaps, and the risks of aerosol transmission of SARS-COV-2. Resuscitation 152, 205-207,2020. DOl:https:// doi.org/ https://doi.org/10.1016/j.resuscitation.2020.05.019. Published online May 14 , accessed July 6.

8. Hunt EA, Walker AR, Shaffner DH, Miller MR, Pronovost PJ. Simulation of inhospital pediatric medical emergencies and cardiopulmonary arrests: highlighting the importance of the first 5 minutes. Pediatrics. 2008;121(1): e34-43 doi:10.1542/peds.2007-0029. Accessed July 2.

9. Mondrup F, Brabrand M, Folkestad L, et al. In-hospital resuscitation evaluated by in situ simulation: a prospective simulation study. Scand J Trauma Resusc Emerg Med. 2011;19:55. https://doi.org/10.1186/1757-724119-55 Published 2011 Oct 6. Accessed October 12.

10. Stewart JA. Focused nurse-defibrillation training: a simple and cost-effective strategy to improve survival from in-hospital cardiac arrest. Scand I Trauma Resusc Emerg Med. 2010;18:42. https://doi.org/10.1186/1757-7241-18-42 Accessed July 2.

11. Ghelichkhani P, Esmaeili M. Prone Position in Management of COVID-19 Patients; a Commentary. Arch Acad Emerg Med. 2020;8(1):e48 Published 2020 Apr 11. Accessed July 5

12. Bhatnagar V, Jinjil K, Dwivedi D, Verma R, Tandon U, et al. J Emerg Trauma Shock. 2018;11(1):31-7. https://doi.org/10.4103/JETS.JETS_58_17 Accessed July 2.

13. Kramer DB, Lo B, Dickert NW. CPR in the Covid-19 era - an ethical framework. N Engl J Med. 2020. https://doi.org/10.1056/NEJMp2010758 Online ahead of print, accessed July 6.

14. Kapoor I, Prabhakar H, Mahajan C. Cardiopulmonary resuscitation in COVID-19 patients-To do or not to? J Clin Anesth. 2020;65:109879. https://doi.org/10 1016/j.jclinane.2020.109879 Published online 2020 May 19. Accessed July 2

\section{Publisher's Note}

Springer Nature remains neutral with regard to jurisdictional claims in published maps and institutional affiliations.

Ready to submit your research? Choose BMC and benefit from:

- fast, convenient online submission

- thorough peer review by experienced researchers in your field

- rapid publication on acceptance

- support for research data, including large and complex data types

- gold Open Access which fosters wider collaboration and increased citations

- maximum visibility for your research: over $100 \mathrm{M}$ website views per year

At BMC, research is always in progress.

Learn more biomedcentral.com/submissions 